\title{
Volatiles and fatty acid analyzes of Tripleurospermum decipiens (Fisch \& C. A. Mey) Bornm and investigation of the extracts for antimicrobial and enzyme inhibitory activities
}

\author{
Gamze GÖGER ${ }^{1}$ (D) İrem YAVAŞ ${ }^{2}$ (D), Süleyman YUR ${ }^{3}$ (D), Yavuz Bülent KÖSE ${ }^{4}$ (D), Gülmira ÖZEK ${ }^{5}$ (D)
}

1 Department of Pharmacognosy, Faculty of Pharmacy, Trakya University, Edirne, 22030 Turkey.

2 Faculty of Pharmacy, Trakya University, Edirne, 22030 Turkey.

3 Medicinal Plant, Drug and Scientific Research Center (AUBIBAM), Anadolu University, Eskişehir, 26470, Turkey.

4 Department of Pharmaceutical Botany, Faculty of Pharmacy, Anadolu University, Eskişehir, 26470 Turkey.

5 Department of Pharmacognosy, Faculty of Pharmacy, Anadolu University, Eskişehir, 26470, Turkey.

* Corresponding Author. E-mail: gamzegoger@trakya.edu.tr (G.G.); Tel. + 0 (284) 235 40 10/3251

Received: 17 December 2020 / Revised: 31 March 2021 / Accepted: 18 April 2021

\begin{abstract}
In this study, the volatiles were obtained from aerial parts of Tripleurospermum decipiens (Fisch \& C.A.Mey) Bornm with microsteam distillation - solid phase microextraction (MSD-SMPE) technique. The fatty acids from T. decipiens were obtained by using the microextraction method with subsequent transesterification with boron trifluoride reagent. The chemical compositions of the volatiles and fatty acid methyl esters was analyzed by Gas Chromatography (GC) and Gas Chromatography/ Mass Spectrometry (GC / MS) techniques. n-Hexane (TDH) and methanol (TDM) extracts of $T$. decipiens were investigated for acetylcholineterase (AChE), $\alpha$-amylase enzyme inhibitions and antimicrobial activities. In vitro inhibition of AChE was monitored by using Ellman's chromogenic agent, and antidiabetic effects of the extracts were spectrophometrically evaluated by inhibition of porcine pancreatic $\alpha$-amylase enzyme. Antimicrobial activities of the extracts were evaluated against Salmonella enterica ATCC 14028, Bacillus subtilis subsp spizizeni ATCC 6633, B. subtilis ATCC 19654, Staphylococcus aureus ATCC 6538, Klebsiella aerogenes ATCC 13048, Candida parapsilosis ATCC 22019 by microdilution method. In vitro $\alpha$-amylase enzyme inhibitory activity was observed for methanol extract $(55.6 \%)$ at $10 \mathrm{mg} / \mathrm{mL}$. The highest AChE inhibition was recorded for $n$-hexane extract $(58.8 \%)$ at concentration $(10$ $\mathrm{mg} / \mathrm{mL}$ ). The extracts were found to be effective against B. subtilis ATCC 19654, B. subtilis subsp spizizeni ATCC 6633 , S. aureus ATCC 6538 and C. parapsilosis ATCC 22019.
\end{abstract}

KEYWORDS: Tripleurospermum decipiens; essential oil; extract; acetylcholineterase; $\alpha$-amylase; antimicrobial.

\section{INTRODUCTION}

The use of plants as a herbal drugs for the treatment of various diseases has a long history. In recent years, a large number of plant species have been investigated for medicinal applications. Herbal remedies have been considered as a dietary supplement for disease prevention and used as complementary medicine [1]. In this scope, increasing evidence and knowledge on their potential benefits have highlighted the demand for herbal products [2]. These products were reported for potential against bacterial infections, cancer [3-5], neurodegenerative disorders, as well as prevention of diabetes [6], and cardiovascular diseases [7].

Alzheimer's disease (AD) is an age-linked chronic neurodegenerative disease defined by memory loss, cognitive dysfunction and restriction in daily activities, and acetylcholinesterase and butyrylcholinesterase enzyme inhibitions have been accepted as a significant strategy for the treatment of AD. [11].

In recent years, it has been observed a high percentage rate in Diabetes mellitus (DM) distribution due to people's lifestyle change, and it affects a large number of people around the world. $a$-Glucosidase and $\alpha$ amylase are key enzymes that catalyze hydrolysis of carbohydrates to glucose monomers. In this case, $\alpha$ glucosidase and $\alpha$-amylase inhibitor drugs reduce blood glucose levels and use in the treatment of DM [1213]. Natural or synthetic drugs have been used to treat high blood glucose levels. Although the mechanism

How to cite this article: Göger G, Yavaş I, Yur S, Köse YB, Özek G. Volatiles and fatty acid analyzes of Tripleurospermum decipiens (Fisch \& C. A. Mey) Bornm and investigation of the extracts for antimicrobial and enzyme inhibitory activities. J Res Pharm. 2021; 25(4): 429-440. 
of the relationship between Alzheimer's and diabetes has not been fully revealed, a lot of factors play a role which includes genetic factors, lifestyle, socioeconomic causes, cardiovascular diseases, inflammation, diabetes, insulin resistance, and it is thought to affect different pathological processes [8-10].

The Asteraceae family comprises approximately 23.000 species in the world. The genus of Tripleurospermum Sch. Bip. is the member of tribe Anthemideae and represented by 31 taxa in the flora of Turkey. Most of the species are distributed worldwide in Europe, Asia, North America, and North Africa [14]. Tripleurospermum species have been traditionally used to cure or lower the pain of several diseases as well as for food purposes [15-17]. Uses of T. parviflorum (Wiild.) Pobed. as antipyretic [18], and T. conoclinium (Boiss.\& Bal.) Hayek for prevention of cough are among the well-known traditional uses of Tripleurospermum species [19]. Ethnobotanical uses of Tripleurospermum species are summarized in Table 1.

Table 1. Etnobotanical uses of Tripleurospermum in Turkey.

\begin{tabular}{|c|c|c|c|c|c|}
\hline Latin name & $\begin{array}{l}\text { Local } \\
\text { name }\end{array}$ & $\begin{array}{l}\text { Part } \\
\text { used }\end{array}$ & Etnobotanical use & $\begin{array}{l}\text { Utilization } \\
\text { method }\end{array}$ & References \\
\hline $\begin{array}{l}\text { T. parviflorum } \\
\text { (Willd.) Pobed. }\end{array}$ & $\begin{array}{l}\text { Beybunik, } \\
\text { Kır } \\
\text { papatyası, } \\
\text { Papatya }\end{array}$ & Cap. & Food & $\begin{array}{l}\text { Eaten } \\
\text { fresh (with } \\
\text { salt) }\end{array}$ & [15] \\
\hline T. parviflorum & Papatya & Flower & Vaginitis & Dec. & [46] \\
\hline $\begin{array}{l}\text { T. conoclinium } \\
\text { (Boiss.\& Bal.) } \\
\text { Hayek }\end{array}$ & Papatya & $\begin{array}{l}\text { Aerial } \\
\text { part }\end{array}$ & Cough & Dec. & [19] \\
\hline T. parviflorum & $\begin{array}{l}\text { Papatya } \\
\text { Papatya }\end{array}$ & Flower & $\begin{array}{l}\text { Throat diseases } \\
\text { Hair care /Colds, }\end{array}$ & $\begin{array}{l}\text { Dec. } \\
\text { Inf / Int. }\end{array}$ & [16] \\
\hline T. parviflorum & & Cap. & $\begin{array}{l}\text { cough, antipyretic, } \\
\text { stomach ache }\end{array}$ & Dec./Ext. & [18] \\
\hline $\begin{array}{l}\text { T. monticolum } \\
\text { (Boiss. \& Huet) } \\
\text { Bornm. }\end{array}$ & $\begin{array}{l}\text { Kir } \\
\text { papatyası }\end{array}$ & Cap. & $\begin{array}{l}\text { Hair care, Colds, } \\
\text { cough, antipyretic, } \\
\text { stomach ache }\end{array}$ & $\begin{array}{l}\text { Dec. } \\
\text { Inf. }\end{array}$ & {$[18]$} \\
\hline $\begin{array}{l}\text { T. sevanense } \\
\text { (Manden.) Pobed. } \\
\text { T. oreadas (Boiss.) }\end{array}$ & Papatya & Cap. & Hair care & Dec./Ext. & [18] \\
\hline $\begin{array}{l}\text { Rech. f. } \\
\text { var. oreades }\end{array}$ & Papatya & Flower & $\begin{array}{l}\text { To ease respiration } \\
\text { and gastric pain }\end{array}$ & Inf. & [47] \\
\hline $\begin{array}{l}\text { T. oreades (Boiss.) } \\
\text { Rech var. oreades }\end{array}$ & $\begin{array}{l}\text { Papatya, } \\
\text { Oşoş }\end{array}$ & Flower & $\begin{array}{l}\text { Dyspnea, abdominal } \\
\text { pain, } \\
\text { gynecologicaldiseases, } \\
\text { arrhythmia, urinary } \\
\text { system infections }\end{array}$ & Dec & [48] \\
\hline T. parviflorum & $\begin{array}{l}\text { Koyun } \\
\text { gözü, } \\
\text { papatya }\end{array}$ & $\begin{array}{l}\text { Aerial } \\
\text { part }\end{array}$ & Diabetes & Dec. & [49] \\
\hline $\begin{array}{l}\text { T. callosum (Boiss. } \\
\text { \& Heldr.) E. } \\
\text { Hossain }\end{array}$ & Papatya & Flower & $\begin{array}{l}\text { Urinary tract } \\
\text { disorders, kidney } \\
\text { stones }\end{array}$ & Inf & [50] \\
\hline $\begin{array}{l}\text { T. disciforme } \\
\text { (C.A.Mey.) Sch. } \\
\text { Bip. }\end{array}$ & $\begin{array}{l}\text { Papatya, } \\
\text { Beybun }\end{array}$ & $\begin{array}{l}\text { Cap. } \\
\text { Leaves }\end{array}$ & Wound healing & Inf & [17] \\
\hline $\begin{array}{l}\text { T. caucasicum } \\
\text { (Willd.) Hayek }\end{array}$ & Beybun & Cap. & $\begin{array}{l}\text { Diabetes disease, } \\
\text { headache, Toothache }\end{array}$ & Inf & [17] \\
\hline $\begin{array}{l}\text { T. transcaucasicum } \\
\text { (Manden.) Pobed }\end{array}$ & Beybun & $\begin{array}{l}\text { Cap, } \\
\text { Leaves }\end{array}$ & $\begin{array}{l}\text { Acne, diabetes, } \\
\text { headache }\end{array}$ & Inf & [17] \\
\hline
\end{tabular}

Cap.: Capitulum, Inf: Infusion, Dec: Decoction, Int: Internal, Ext: External

Phytochemical investigations on Tripleurospermum species have generally been focused on essential oil content [20-24]. A summary of previous studies on essential oil chemical composition of Tripleurospermum species is reported in Table 2. In general, $\beta$-farnesene $(22.5 \%), \beta$-sesquiphellandrene $(17.9 \%)$ [21], neryl acetate $(12.8 \%),(E)-\beta$-farnesene $(12.5 \%)$, phytol (12.1\%) [24], globulol (13.5\%) and sesquiphellandrene $(9.3 \%)$ [25]; (Z)- $\beta$-farnesene (18.2\%), 1-epi-cubenol (16.1\%) [22] were reported as common volatiles compounds while dioxoipran derivative [26] and flavonoids were detected as non-volatile constituents in the extracts [27]. Fatty acid compounds of Tripleurospermum species are summarized in Table 3. 
Table 2. Literature overview on essential oil compounds of Tripleurospermum species.

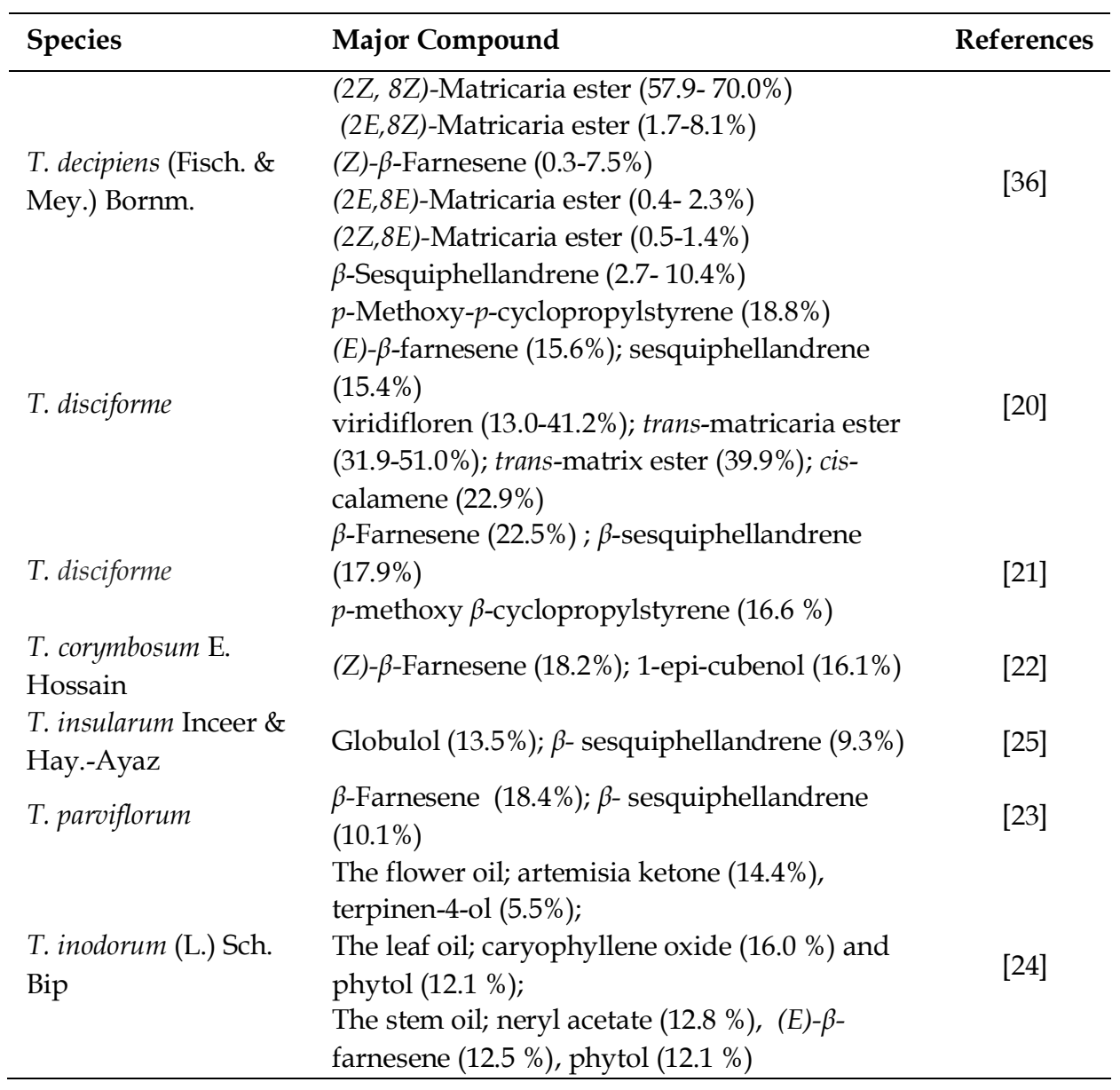

Table 3. Literature overview on fatty acid compounds of Tripleurospermum species.

\begin{tabular}{llc}
\hline Species & Fatty acids & References \\
\hline T. callosum & Linoleic acid (16.2\%), & {$[51]$} \\
T. callosum & Hexadecanoic acid (17.9\%) & {$[51]$} \\
T. parviflorum & Hexadecanoic acid (6.2\%) & \\
& Palmitic acid (38.6\%) & {$[39]$} \\
T. tenuifolium & Linoleic acid (20.6\%) & \\
& Oleic acid (9.6\%) & \\
T. decipiens & Palmitic acid (47.6\%) & Linoleic acid (18.4\%) \\
& Oleic acid (8.5 \%) & \\
\hline
\end{tabular}

T. decipiens is known as "Sar1 papatya" and it grows in Northwest, West, Central and South Anatolia in Turkey. In this study, we aimed to reveal the chemical composition of the essential oil and fatty acid content and biological properties of the extracts of T. decipiens. The chemical composition of the essential oil and fatty acid was determined by Gas Chromatography (GC) and Gas Chromatography / Mass spectrometry (GC / MS) methods. The extraction of fatty acids from $T$. decipiens has been carried out using the "Fatty Acid Extraction" Kit. Methyl esters of the fatty acids were obtained with Boron trifluoride-methanol solution and analyzed by GC-FID/MS (28). In vitro AChE and $\alpha$-amylase enzyme inhibitions of the extracts were determined by spectrophotometric method with Ellman's and KI/ $\mathrm{I}_{2}$ reagents, respectively. Antimicrobial activities of the extracts were evaluated against Salmonella enterica ATCC 14028, Bacillus subtilis subsp. spizizeni ATCC 6633, Bacillus subtilis ATCC 19654, Staphylococcus aureus ATCC 6538, Klebsiella aerogenes ATCC 13048, Candida parapsilosis ATCC 22019 by microdilution method. 
The aim of this paper was to give characterization of the volatile oil and fatty acid compositions and biological properties of the apolar and polar extracts of $T$. decipiens. To the best of our knowledge, there is no previous report on anti-microbial, anti-acetylcholinesterase, anti-amylase activities for T. decipiens.

\section{RESULTS AND DISCUSSION}

\subsection{Chemical composition of the volatiles of Tripleurospermum decipiens}

In the present study, we investigated the volatiles composition from aerial parts of $T$. decipiens with MSD-SPME technique in tandem with GC-MS/FID techniques. The list of the volatile compounds identified in $T$. decipiens with their relative retention indices and relative percentages is reported in Table 4.

Forty-eight volatile compounds have been identified in aerial parts of $T$. decipiens, representing for $94.3 \%$ of the total volatiles. The main volatile compounds were presented by isomeric polyacetylenic constituents representing $61.7 \%$ of total volatiles. The main constituents were found to be as $(2 Z, 8 Z)$ matricaria ester $(31.4 \%),(2 E, 8 Z)$-matricaria ester $(12.3 \%),(2 E, 8 E)$-matricaria ester $(10.9 \%)$ and $(2 Z, 8 E)$ matricaria ester $(6.7 \%)$. The main compound groups detected in the volatiles of $T$. decipiens are presented in Table 5. The oxygenated monoterpenes comprised the second major compound group $(9.2 \%)$. The main representatives of this group were found to be as linalool $(2.4 \%)$ and linalyl acetate $(1.5 \%)$. Modhephene $(2.9 \%),(Z)-\beta$-farnesene $(0.5 \%)$ and $a$-isocomene $(0.3 \%)$ were determined in the group of the sesquiterpene hydrocarbons (3.7 \%). The oxygenated sesquiterpenes $(1.7 \%)$ were presented by caryophyllene oxide $(1.0 \%)$, spathulenol $(0.4 \%)$ and hexahydro-farnesylacetone $(0.3 \%)$. Aliphatic ketones constituted $5.9 \%$ of the total volatiles with 6-methyl-5-hepten-2-one (4.1\%) as the main representative.

Literature overview on essential oil compounds of Tripleurospermum species was given in Table 2 . The dried flowers of $T$. decipiens from two different populations were investigated for essential oil compositions by Kürkçüoğlu et al. [36]. According to this study, in the flower essential oil $(2 Z, 8 Z)$-matricaria ester (57.9$70.0 \%), \beta$-sesquiphellandrene $(2.7-10.4 \%),(2 E, 8 Z)$-matricaria ester $(1.7-8.1 \%),(Z)-\beta$-farnesene $(0.3-7.5 \%)$, $(2 E, 8 E)$-matricaria ester (0.4-2.3 \%), and (2Z,8E)-matricaria ester (0.5-1.4 \%) were found as the main components. The differences in essential oil contents of previous publications may be due to edafic factors as well as to different techniques applied for obtaining of the volatiles from the plant materials.

\subsection{Fatty acids compositions}

Fatty acid composition of T. decipiens was given in Table 6. Gas-chromatographic analysis resulted with eight compounds, representing $100.0 \%$ of fatty acids. Palmitic $(42.1 \%)$, nonadecanoic $(19.7 \%)$ and linoleic $(19.0 \%)$ acids were found as main ones in T. decipiens.

In literature there are several reports about fatty acid composition of Tripleurospermum species. Palmitic and linoleic acids generally found as main compounds of different Tripleurospermum species (Table 3). Ayaz et al. reported about fatty acid composition of the plant. Pentadecanoic acid (55.2\%) and tetracosanoic acid $(64.3 \%)$ were reported for T. decipiens [37].

\subsection{Antimicrobial activity (MIC, $\mu \mathrm{g} / \mathrm{mL})$}

The effects of T. decipiens extracts and standards are given in Table 7 against S. enterica ATCC 14028, $K$. aerogenes ATCC 13048, B. subtilis subsp. spizizeni ATCC 6633, B. subtilis ATCC 19654, S. aureus ATCC 6538, and C. parapsilosis ATCC ${ }^{8}$ 22019. As can be seen from Table 7, n-hexane extract more active with MIC $=156.25 \mu \mathrm{g} / \mathrm{mL}$ against B. subtilis ATCC 19654 and C. parapsilosis ATCC ${ }^{8} 22019$ than the other pathogens. The methanol extract was observed active against S. enterica ATCC 14028, K. aerogenes ATCC 13048 and C. parapsilosis ATCC 22019 with MIC $=312.5$ value $\mu \mathrm{g} / \mathrm{mL}$.

Tripleurospermum species have reported on anti-microbial, anti-acetylcholinesterase, analgesic, antioxidant, anti-inflammatory, antiproliferative, anti-ulcer, and cytotoxic activities [25; 27; 38-43]. Generally, there are some reports about antimicrobial activity genus on Tripleurospermum. The extract of $T$. disciforme aerial parts was examined against S. epidermidis, S. aureus, B. cereus and Pseudomonas aeruginosa. The extract $(64 \mathrm{mg} / \mathrm{mL})$ exhibited antimicrobial effects only against $S$. aureus $(14 \mathrm{~mm})$ and S. epidermidis $(12 \mathrm{~mm})$ [27]. In another study, antimicrobial activity of $T$. disciforme essential oil was investigated against Serratia marcescens PTCC 1330, Enterobacter aerogenes PTCC 10009, Proteus vulgaris (Lio), Citrobacter amalonaticus (Lio), B. cereus ATCC 7064, B. megaterium PTCC 1672, S. subrogation (Lio), and S. aureus ATCC 6633. The lowest MIC value $(4 \mu \mathrm{L} / \mathrm{mL})$ of T. disciforme oil was observed against S. aureus ATCC 6633 and B. cereus ATCC 7064 [21]. The ethanol extract of T. conoclinium Boiss. Ball. (aerial parts) was tested against Mycobacterium tuberculosis H37Rv with MIC $\leq 100 \mu \mathrm{g} / \mathrm{mL}$ [44]. The antimicrobial activities of $n$-hexane, methanol, ethanol, ethyl acetate 
and water extracts of T. parviflorum (Willd.) Pobed. were reported against P. aeroginosa ATCC 27853, E. cloacae ATCC 13047, E. faecalis ATCC 29212, S. aureus ATCC 6538P, S. aureus ATCC 29213, E. coli ATCC 29998, E. coli ATCC 25922, E. coli ATCC 11230, and C. albicans ATCC 10239 [45].

Table 4. Chemical composition of the volatiles of Tripleurospermum decipiens.

\begin{tabular}{|c|c|c|c|}
\hline No & RRI & Compound & $\%$ \\
\hline 1 & 1335 & (E)-2-Heptenal & 0.7 \\
\hline 2 & 1348 & 6-Methyl-5-hepten-2-one & 4.1 \\
\hline 3 & 1400 & Nonanal & 1.7 \\
\hline 4 & 1400 & Tetradecane & 0.6 \\
\hline 5 & 1415 & 4,8-Dimethyl-1,3,7-nonatriene & 0.1 \\
\hline 6 & 1416 & 3-Octen-2-one & 0.5 \\
\hline 7 & 1441 & (E)-2-Octenal & 0.8 \\
\hline 8 & 1452 & 1-Octen-3-ol & 0.8 \\
\hline 9 & 1474 & Dihydromyrcenol, 6,10- & 0.3 \\
\hline 10 & 1479 & $(E, Z)-2,4$-Heptadienal & 0.6 \\
\hline 11 & 1496 & 2-Ethyl hexanol & 0.8 \\
\hline 12 & 1506 & Decanal & 1.2 \\
\hline 13 & 1507 & $(E, E)-2,4$-Heptadienal & 0.6 \\
\hline 14 & 1532 & Camphor & 0.3 \\
\hline 15 & 1532 & $a$-Isocomene & 0.3 \\
\hline 16 & 1553 & Linalool & 2.4 \\
\hline 17 & 1565 & Linalyl acetate & 1.5 \\
\hline 18 & 1525 & Modhephene & 2.9 \\
\hline 19 & 1573 & $(E, E)-3,5$-Octadien-2-one & 0.4 \\
\hline 20 & 1602 & 6-Methyl-3,5-heptadien-2-one & 0.9 \\
\hline 21 & 1611 & Terpinen-4-ol & 0.3 \\
\hline 22 & 1655 & (E)-2-Decenal & 0.9 \\
\hline 23 & 1664 & Nonanol & 0.3 \\
\hline 24 & 1668 & (Z)- $\beta$-Farnesene & 0.5 \\
\hline 25 & 1694 & Neral & 0.3 \\
\hline 26 & 1709 & $a$-Terpinyl acetate & 0.4 \\
\hline 27 & 1715 & $(E, E)-2,4$-Nonadienal & 0.2 \\
\hline 28 & 1719 & Borneol & 0.2 \\
\hline 29 & 1740 & Geranial & 0.6 \\
\hline 30 & 1764 & (E)-2-Undecenal & 0.5 \\
\hline 31 & 1808 & Nerol & 0.3 \\
\hline 32 & 1827 & $(E, E)-2,4$-Decadienal & 0.3 \\
\hline 33 & 1857 & Geraniol & 0.8 \\
\hline 34 & 1868 & (E)-Geranyl acetone & 0.4 \\
\hline 35 & 1871 & Neryl isovalerate & 0.3 \\
\hline 36 & 1873 & $\begin{array}{l}\text { 1-Isobutyl 4-isopropyl 3-isopropyl-2,2-dimethyl succinate } \\
\text { (= 2,2,4-trimethyl-3-carboxyisopropyl-isobutyl pentanoate) }\end{array}$ & 0.6 \\
\hline 37 & 2008 & Caryophyllene oxide & 1.0 \\
\hline 38 & 2015 & trans- $\beta$-Ionone-5,6-epoxide & 0.6 \\
\hline 39 & 2131 & Hexahydro-farnesylacetone & 0.3 \\
\hline 40 & 2144 & Spathulenol & 0.4 \\
\hline 41 & 2192 & Nonanoic acid & 0.8 \\
\hline 42 & 2210 & $(2 \mathrm{E}, 8 \mathrm{Z})-$ Matricaria ester & 12.3 \\
\hline 43 & 2221 & Isocarvacrol (=4-Isopropyl-2-methyl phenol) & 0.5 \\
\hline 44 & 2227 & 8Z-2,3-Dihydromatricaria ester & 0.4 \\
\hline 45 & 2298 & Decanoic acid & 0.6 \\
\hline 46 & 2291 & $(2 E, 8 E)$-Matricaria ester & 10.9 \\
\hline 47 & 2336 & $(2 Z, 8 Z)$-Matricaria ester & 31.4 \\
\hline \multirow[t]{2}{*}{48} & 2435 & $(2 Z, 8 \mathrm{E})$-Matricaria ester & 6.7 \\
\hline & & Total & 94.3 \\
\hline
\end{tabular}

RRI, relative retention index experimentally calculated based on retention of $n$-alkanes; \%, calculated from flame ionization detector data. The data are presented as relative $\%$ by weight for each component detected in $T$. decipiens. 
There is no previous biological studies for $T$. decipiens in the literature, although considerable reports conducted due to the widespread traditional use of Tripleurospermum species. To the best of our knowledge, the present work is the first report on antimicrobial activity of $T$. decipiens extracts.

Table 5. Distribution of the main compound groups detected in the volatiles of Tripleurospermum decipiens.

\begin{tabular}{lc}
\hline \multicolumn{1}{c}{ Compound group } & $\%$ \\
\hline Aliphatic aldehydes & 7.5 \\
Aliphatic ketones & 5.9 \\
Oxygenated monoterpenes & 9.2 \\
Sesquiterpene hydrocarbons & 3.7 \\
Oxygenated sesquiterpenes & 1.7 \\
Isomeric polyacetylenic constituents & 61.7 \\
Fatty acids & 1.4 \\
\hline
\end{tabular}

Table 6. Fatty acid composition of Tripleurospermum decipiens.

\begin{tabular}{ccclc}
\hline No & RRI $^{\mathbf{a}}$ & RRI $^{\mathbf{b}}$ & \multicolumn{1}{c}{ Compound } & \% $^{\mathbf{c}}$ \\
\hline $\mathbf{1}$ & 1600 & $1604^{\mathrm{d}}$ & $10: 0$ (Methyl caprate) & 2.1 \\
$\mathbf{2}$ & 1810 & $1807^{\mathrm{e}}$ & $12: 0$ (Methyl laurate) & 1.1 \\
$\mathbf{3}$ & 2018 & $2014^{\mathrm{f}}$ & $14: 0$ (Methyl myristate) & 3.5 \\
$\mathbf{4}$ & 2223 & $2223[13]$ & $16: 0$ (Methyl palmitate) & $\mathbf{4 2 . 1}$ \\
$\mathbf{5}$ & 2436 & $2445[14]$ & $18: 0$ (Methyl stearate) & 6.7 \\
$\mathbf{6}$ & 2468 & $2472[14]$ & $18: 1 \omega 9$ (Methyl oleate) & 5.8 \\
$\mathbf{7}$ & 2509 & $2502[15]$ & $18: 2 \omega 6$ (Methyl linoleate) & $\mathbf{1 9 . 0}$ \\
$\mathbf{8}$ & 2512 & $2513[14]$ & $19: 0$ (Methyl nonadecanoate ) & 19.7
\end{tabular}

Total: $\quad 100.0$

RRIa: relative retention index experimentally calculated based on retention of $n$-alkanes, RRIb: relative retention index reported in literature for constituents analyzed on polar column; c The data are presented as relative \% by weight for each component detected in Tripleurospermum decipiens; \%, calculated from flame ionization detector data; $\mathrm{d}$ [52], e [53]- f [54]

\section{4. $\alpha$-Amylase inhibitory activity}

In the present work we evaluated the inhibitory potential of $T$. decipiens extracts towards $\alpha$-amylase, key enzyme in carbonhydrate methabolism. The evaluation was carried out in vitro using microplate titer assay.

$\alpha$-Amylase enzyme inhibition results for $T$. decipiens $n$-hexane and methanol extracts are given in Table 8. The methanol extract inhibited $\alpha$-amylase $\left(55.6 \%, \mathrm{IC}_{50} 7.8 \mathrm{mg} / \mathrm{mL}\right)$ better than $n$-hexane extract $(32.9 \%)$. Comparison of the obtained $\mathrm{IC}_{50}$ values demonstrated that the crude methanol extract of $T$. decipiens had weaker activity than pure standard inhibitor (acarbose), these results have been evaluated as promising items for continuation of investigations. There is no previous report about $\alpha$-amylase inhibitory activity of $T$. decipiens.

\subsection{Acetylcholinesterase inhibitory activity}

In the present work we evaluated the inhibitory potential of $T$. decipiens extracts towards acetylcholinesterase, key enzyme in pathogenesis of Alzheimer's disease. The evaluation was carried out in vitro using microplate titer assay. It has been shown that $n$-hexane extract of $T$. decipiens demonstrated inhibitory effect $\left(\mathrm{IC}_{50} 6.8 \mathrm{mg} / \mathrm{mL}\right.$ ) towards $\mathrm{AChE}$ enzyme while no $\mathrm{AChE}$ inhibition was observed for the methanol extract (Table 8). Although, comparison of the obtained $\mathrm{IC}_{50}$ values demonstrated that the crude hexane extract had weaker activity than pure standard inhibitor (galanthamin), these results have been evaluated as promising items for continuation of investigations. In the literature, it was observed that $\mathrm{AChE}$ 
activity studies mostly focused on $T$. disciforme. Methanol extract of $T$. disciforme at $5 \mu \mathrm{g} / \mathrm{mL}$ was reported to inhibit AChE enzyme (71.18 $\pm 4.9 \%)$ [40]. Servi et al. reported about anti-AChE activity of the flower essential oil of T. inodorum (53.35\% at $20 \mathrm{mg} / \mathrm{mL}$ ) [24]. To the best of knowledge, there is no previous report on AChE inhibitory activity of $T$. decipiens.

Table 7. Antimicrobial activity of Tripleurospermum decipiens extracts (minimum inhibitory concentration, $\mu \mathrm{g} / \mathrm{mL})$.

\begin{tabular}{|c|c|c|c|c|c|c|}
\hline \multirow[b]{2}{*}{ Samples } & \multicolumn{6}{|c|}{ Microorganism } \\
\hline & $\begin{array}{l}\text { S. enterica } \\
\text { ATCC } \\
14028\end{array}$ & $\begin{array}{c}\text { B. subtilis } \\
\text { subsp. spizizeni } \\
\text { ATCC } 6633\end{array}$ & $\begin{array}{l}\text { B. subtilis } \\
\text { ATCC } \\
19654\end{array}$ & $\begin{array}{l}\text { S. aureus } \\
\text { ATCC } \\
6538\end{array}$ & $\begin{array}{l}\text { K. aerogenes } \\
\text { ATCC } 13048\end{array}$ & $\begin{array}{c}\text { C. parapsilosis } \\
\text { ATCC } 22019\end{array}$ \\
\hline TDH & 312.5 & 312.5 & 156.25 & 312.5 & 312.5 & 156.25 \\
\hline TDM & 312.5 & 625 & 625 & 625 & 312.5 & 312.5 \\
\hline Cefuroxime & 16 & 2 & 2 & 2 & 64 & - \\
\hline Moxifloxacin & $0.125>$ & $0.125>$ & $0.125>$ & $0.125>$ & $0.125>$ & - \\
\hline Ampicilline & 0.25 & 0.5 & $0.125>$ & 2 & 16 & - \\
\hline Fluconazole & - & - & - & - & - & $>64$ \\
\hline
\end{tabular}

Table 8. Enzyme inhibitory activities of Tripleurospermum decipiens extracts.

\begin{tabular}{ccccc}
\hline Assays & $\begin{array}{c}\mathrm{TDH} \\
\mathrm{IC} 50, \mathrm{mg} / \mathrm{mL}\end{array}$ & $\begin{array}{c}\text { TDM } \\
\mathrm{IC}_{50}, \mathrm{mg} / \mathrm{mL}\end{array}$ & $\begin{array}{c}\text { Acarbose } \\
\mathrm{IC}_{50}, \mathrm{mg} / \mathrm{mL}\end{array}$ & $\begin{array}{c}\text { Galantamine } \\
\mathrm{IC}_{50}, \mathrm{mg} / \mathrm{mL}\end{array}$ \\
\hline $\begin{array}{c}\mathrm{a} \text {-Amylase } \\
\text { inhibitory activity }\end{array}$ & $>10$ & 7.8 & 0.08 & - \\
$\begin{array}{c}\text { Acetylcholinesterase } \\
\text { inhibitory activity }\end{array}$ & 6.8 & $\mathrm{~N} / \mathrm{A}$ & - & 0.01
\end{tabular}

TDH: T. decipiens n-hexane extract, TDM: T. decipiens methanol extract; a the extracts were tested in concentration 10 $\mathrm{mg} / \mathrm{mL}$; N/A: Not active.

\section{CONCLUSION}

The present study is the first investigation of Tripleurospermum decipiens extracts for anti-microbial, anti-acetylcholinesterase, and anti- $\alpha$-amylase activities. The $n$-hexane extract of $T$. decipiens has a reasonable potential activity against B. subtilis ATCC 19654 and C. parapsilosis ATCC 22019 eventhough its antimicrobial activity is not very strong. The extract also shows acetylcholinesterase inhibitory activity.

\section{MATERIALS AND METHODS}

\subsection{Plant material}

Aerial parts of Tripleurospermum decipiens were collected in Eskişehir province of Turkey (ŞelaleKirazlı road 2nd km, roadside, calcareous soil) on July 02, 2019. The plant material was dried under the shade and identification was performed by Prof. Dr. Y. B. Köse (Anadolu University). The voucher specimen was kept in Anadolu University Herbarium (ESSE 15609).

\subsection{Chemicals}

5,5-Dithio-bis-(2-nitrobenzoic acid (DTNB), acetylcholinesterase (AChE) from Electrophorus electricus (electric eel, Type VI-S, 200-1000 units/mg protein), bovine serum albumin (BSA), acetylthiocholine iodide (ATCI), galanthamine hydrobromide from Lycoris sp., $\alpha$-amylase from porcine pancreas (Type VI-B, $\geq 10$ units/mg solid) and acarbose were purchased from Sigma-Aldrich (St. Louis, MO, USA). Starch-soluble extra pure iodine and potassium iodide were purchased from Merck (Darmstadt, Germany). Sodium phosphate, disodium phosphate, aluminum chloride, ultrapure water, methanol $(\mathrm{MeOH})$, dimethyl sulfoxide (DMSO) were extra pure analytical grade. A C9-C40 n-alkane standard solution was purchased from Fluka (Buchs, Switzerland). 


\subsection{Preparation of extracts}

The dried aerial parts of $T$. decipiens $(20 \mathrm{~g})$ were subjected to maceration with $n$-hexane $(200 \mathrm{~mL} \times 3)$ and methanol $(200 \mathrm{~mL} \times 3)$ respectively at room temperature for $24 \mathrm{~h}$. The solvents were evaporated in vacuo. The dried extracts were kept at $4^{\circ} \mathrm{C}$ before biological activities tests.

\subsection{Extraction of volatiles with microsteam distillation-solid phase microextraction (MSD-SPME)}

The extraction of the volatiles was carried out from T. decipiens aerial parts using MSD-SMPE technique [29]. The ground aerial parts of the plant material $(0.5 \mathrm{~g})$ were put in $25 \mathrm{~mL}$ round bottom flask, and $3 \mathrm{~mL}$ of water was added. The flask was fitted with a Claisen distillation head with plug and a condenser set up for refluxing rather than distillation. The threaded plug was used for SPME fiber assembly. A manual SPME holder and Polydimethylsiloxane/Divinylbenzene (PDMS/DVB) fiber "blue type" (65 $\mu \mathrm{m})$ were used for the extraction of volatiles. Previously, the fiber was conditioned at $250^{\circ} \mathrm{C}$ for $10 \mathrm{~min}$ before the experiment. Different extraction periods were applied to optimize experiment conditions. The extraction time for the volatiles was $3 \mathrm{~min}$. After trapping the volatiles were subsequently subjected to GC-MS/FID analyses. Thermal desorption of analytes from the fiber coating was performed by injection of the fiber in the injection port (at $250^{\circ} \mathrm{C}$ ) for $5 \mathrm{~min}$.

\subsection{Lipid extraction and fatty acid derivatization}

The Lipid Extraction Kit used for the extraction of the total lipids from T. decipiens. According to protocol, $0.15 \mathrm{~g}$ mill-ground plant material was treated with a $3 \mathrm{~mL}$ solvent containing chloroform: methanol (2:1). After homogenizing and vortexing of mixture, $0.5 \mathrm{~mL}$ of an aqueous buffer of the kit was added, and the sample was mixed by a vortex again. Subsequently, the extraction solution was poured into a syringe system containing a filter. The eluted solvent contained the chloroform phase with total lipids. Then, aliquot $200 \mu \mathrm{L}$ of the total lipids were dried under a stream of nitrogen for subsequent transesterification. After drying, $1 \mathrm{~mL}$ of $\mathrm{BF}_{3}-\mathrm{MeOH}$ solution and $0.3 \mathrm{~mL}$ of $n$-hexane were added. The mixture was heated at $95^{\circ} \mathrm{C}$ for one hour under reflux. Then, $1 \mathrm{~mL}$ of $n$-hexane and $1 \mathrm{~mL}$ of distilled water were added. The mixture was vortexed and centrifuged at $500 \times \mathrm{g}$ for $5 \mathrm{~min}$. The top hexane layer was transferred into a vial and then injected into the GC-MS/FID system.

\subsection{Gas chromatography analysis}

GC-MS analysis was examined by an Agilent 6890N GC and Agilent 5975 GC/MSD systems (Agilent Technologies, USA). HP-Innowax FSC column $(60 \mathrm{~m} \times 0.25 \mathrm{~mm}, 0.25 \mu \mathrm{m}$ film thickness, Agilent, USA) was used with a helium carrier gas at $0.8 \mathrm{~mL} / \mathrm{min}$ as reported previously [29].

\subsubsection{Identification of the volatile constituents}

The volatile constituents and fatty acid methyl esters were determined by co-injection with standards. In addition, compound identities were confirmed by comparison of their mass spectra with those in the Wiley GC/MS Library (Wiley, NY, USA), MassFinder software 4.0 (Dr. Hochmuth Scientific Consulting, Hamburg, Germany), Adams Library, and NIST Library. Confirmation was also achieved using the in-house "Başer Library of Essential Oil Constituents" database, obtained from chromatographic runs of pure compounds performed with the same equipment and conditions. $\mathrm{A} \mathrm{C}_{8}-\mathrm{C}_{40} \mathrm{n}$-alkane standard solution was used to spike the samples for the determination of relative retention indices (RRI). Relative percentage amounts of the separated compounds were calculated from FID chromatograms.

\subsection{Antimicrobial activity (MIC, $\mu \mathrm{g} / \mathrm{mL}$ )}

The extracts of $T$. decipiens were tested for an antimicrobial activity against following microbial strains: S. enterica ATCC 14028, K. aerogenes ATCC 13048, B. subtilis subsp. spizizeni ATCC 6633, B. subtilis ATCC 19654, S. aureus ATCC 6538, and C. parapsilosis ATCC 22019 according to previously reported microdilution method [30-31]. The extracts were dissolved in DMSO. The antimicrobial activity of the extracts was evaluated in comparison to moxifloxacin, cefuroxime, ampicillin, and fluconazole (obtained from Sanovel Pharm. Ind.). The Minimum Inhibitory Concentration (MIC) values of the extracts was evaluated with a slight modification of broth microdilution method [32-33]. The extracts were diluted two-fold initially with a final concentration range of 2500 to $19.53 \mu \mathrm{g} / \mathrm{mL}$. Standard antimicrobial drugs ampicillin, cefuroxime, and fluconazole $(64-0.125 \mu \mathrm{g} / \mathrm{mL})$ were prepared within DMSO and water. The positive growth controls (to assess the presence of turbidity) were performed in wells not containing antimicrobial drugs. The microbial 
growth was observed by adding $20 \mu \mathrm{L}$ of resazurin $(0.01 \%)$ with minor modifications of CLSI standards. A change from blue to pink indicated a reduction of resazurin, so it showed microbial growth. MIC determined as the lowest drug concentration that prevented this color change. The tests were carried out in triplicate for calculation of the mean of MIC.

\subsection{Determination of $\alpha$-amylase inhibition}

The antidiabetic activity of $T$. decipiens extracts was determined upon inhibition of the $\alpha$-amylase enzyme that involved in hydrocarbon's metabolism. The iodine/potassium iodide $\left(\mathrm{I}_{2} / \mathrm{KI}\right)$ method was used [34]. The extracts stock solutions $(10 \mathrm{mg} / \mathrm{mL})$ were prepared in methanol (with $10 \% \mathrm{DMSO}$ ). In the experiment, the enzyme $(0.8 \mathrm{U} / \mathrm{mL})$ was prepared in sodium phosphate buffer $(20 \mathrm{mM}, \mathrm{pH} 6.9)$. The substrate solution $(0.05 \%)$ was prepared by dissolving of soluble potato starch $(10 \mathrm{mg})$ in $20 \mathrm{~mL}$ ultrapure water then boiling for $10 \mathrm{~min}$ and cooling to room temperature before use. In the experiment, $20 \mathrm{mM}$ sodium phosphate buffer ( $\mathrm{pH}$ 6.9) was pipetted in the 96-well flat bottom plates with multichannel automatic pipette (Eppendorf Research ${ }^{\circledR}$ plus, Germany), then $25 \mu \mathrm{L}$ of sample solution and $50 \mu \mathrm{L}$ of $\alpha$-amylase $(0.8 \mathrm{U} / \mathrm{mL}$ in buffer) were added and incubated for $10 \mathrm{~min}$ at $37^{\circ} \mathrm{C}$. After incubation, $50 \mu \mathrm{L}$ of substrate solution was added to the mixture. The mixture was subjected to a second incubation for $10 \mathrm{~min}$ at $37^{\circ} \mathrm{C}$. The reaction was stopped by addition of $25 \mu \mathrm{L}$ of $\mathrm{HCl}$ solution $(1 \mathrm{M})$. Finally, $100 \mu \mathrm{L}$ of $\mathrm{I}_{2} / \mathrm{KI}$ reagent was added to the wells. The sample blanks contained all reaction reagents and $50 \mu \mathrm{L}$ of buffer instead of enzyme. The control wells contained all reaction reagents and $25 \mu \mathrm{L}$ of solvent (instead of the sample solution). The absorbance values were recorded at $630 \mathrm{~nm}$. The percentage inhibition of the $\alpha$-amylase activity (Inh\%) was calculated according to Equation 1. Acarbose (inhibitor of $\alpha$-amylase) prepared in concentration $0.25 \mathrm{mg} / \mathrm{mL}$ was used as the positive control. For determination of $\mathrm{IC}_{50}$ values the microdilution tests have been carried out. Minimum of twelve different concentrations have been prepared by means of sequential dilution of the stock solution of the extract were used for calculating the $\mathrm{IC}_{50}$ value. In total, twelve diluted solutions of the sample stock solution (10.0; $5.0 ; 2.5 ; 1.25 ; 0.625 ; 0.312 ; 0.156 ; 0.078 ; 0.039 ; 0.019 ; 0.009 ; 0.0048 \mathrm{mg} / \mathrm{mL}$ ) were subjected to evaluation for enzyme inhibitory effect. $\mathrm{IC}_{50}$ calculations were done by using Sigma Plot 12.0 software. The percentage of inhibition was calculated according to Eq. 1:

$$
\begin{aligned}
& \text { Inhibition } \%=\frac{\left(A b s_{\text {contr }}-A b s_{\text {contr blank }}\right)-\left(A b s_{\text {sample }}-A b s_{\text {sample blank }}\right)}{\left(A b s_{\text {contr }}-A b s_{\text {contr blank }}\right)} \times 100
\end{aligned}
$$

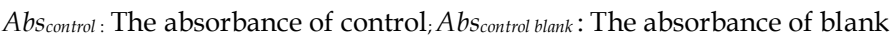

$$
\begin{aligned}
& A b s_{\text {sample }} \text { The absorbance of sample; } A b s_{\text {sample blank }} \text { : The absorbance of blank }
\end{aligned}
$$

\subsection{Determination of AChE inhibition}

Acetylcholinesterase (AChE) inhibition of the extracts was evaluated according to Ellman's method [35] with a slight modification. The extracts stock solutions $(10 \mathrm{mg} / \mathrm{mL}$ ) were prepared in methanol (with $10 \%$ DMSO). In experiment, $25 \mu \mathrm{L}$ of the sample solution, $50 \mu \mathrm{L}$ of buffer, and $25 \mu \mathrm{L}$ of $\mathrm{AChE}(0.22 \mathrm{U} / \mathrm{mL})$ solution were added into the 96-well (flat-bottom) plates, and incubated at $25^{\circ} \mathrm{C}$ for $15 \mathrm{~min}$. After that, 125 $\mu \mathrm{L}$ of Ellman's reagent, DTNB $(3.0 \mathrm{mM})$ and $25 \mu \mathrm{L}$ of the substrate ATCI $(15 \mathrm{mM})$ were added. The mixture was allowed to stand at $25^{\circ} \mathrm{C}$ for $15 \mathrm{~min}$, and the absorbance was recorded at $412 \mathrm{~nm}$ by a microplate reader (Biotek Powerwave XS, USA). Galanthamine solution was prepared in concentration $0.02 \mathrm{mg} / \mathrm{mL}$ and used as the positive control. Similarly, a blank control was prepared by adding the sample solution to all reaction reagents and added $25 \mu \mathrm{L}$ of the buffer instead of the enzyme. The control wells contained all the reagents without the sample. For determination of $\mathrm{IC}_{50}$ values the microdilution tests have been carried out. The percentage of inhibition was calculated according to Eq. 2. The mean standard error ( $\pm S E M)$ was used for evaluation of data.

$$
\text { Inh } \%=\frac{A b s_{\text {contr }}-A b s_{\text {sample }}}{A b s_{\text {contr }}} \times 100
$$


Acknowledgements: This work was partially supported by the TÜBITAK (Project SBAG 218S812).

Author contributions: Concept - G.G; İ.Y.; Design-G.G.; Supervision - G.G.; Resources- G.G.; Y.B.K.; G.Ö.; MaterialsG.G.; Y.B.K.; G.Ö.; Data Collection and/or Processing - G.G., S.Y.; G.Ö.; Analysis and/or Interpretation - G.G.; İ.Y.; S.Y.; G.Ö.; Literature Search - G.G.; İ.Y.; Writing - G.G.; Critical Reviews - G.G.; I.Y.; S.Y.; Y.B.K.; G.Ö.

Conflict of interest statement: The authors declare that there are no conflicts of interest.

\section{REFERENCES}

[1] Ernst E. The efficacy of herbal medicine-an overview. Fund Clin Pharmacol 2015; 19 (4): 405-409. [CrossRef]

[2] Karimi A, Majlesi M, Rafieian-Kopaei M. Herbal versus synthetic drugs; beliefs and facts. J Nephropharmacol. 2015; 4 (1): 27. [CrossRef]

[3] Assaf AM, Haddadin RN, Aldouri NA, Alabbassi R, Mashallah S, Mohammad M, Bustanji Y. Anti-cancer, antiinflammatory and anti-microbial activities of plant extracts used against hematological tumors in traditional medicine of Jordan. J Ethnopharmacol. 2013; 145 (3): 728-736. [CrossRef]

[4] Acevedo-Fani A, Salvia-Trujillo L, Rojas-Graü MA, Martin-Belloso O. Edible films from essential-oil-loaded nanoemulsions: Physicochemical characterization and antimicrobial properties. Food Hydrocoll. 2015; 47: 168-177. [CrossRef]

[5] Boshra SA, Hussein MA. Cranberry extract as a supplemented food in treatment of oxidative stress and breast cancer induced by n-methyl-n-nitrosourea in female virgin rats. Int J Phytomed. 2016; 8: 217-227. [CrossRef]

[6] Cazzola R, Cestaro B. Antioxidant spices and herbs used in diabetes. In: V. Preedy (Ed.), Diabetes: Oxidative stress and dietary antioxidants. Academic Press, 2014, pp. 89-97. [CrossRef]

[7] Davison C, Levendal RA, Frost CL. Cardiovascular benefits of an organic extract of Tulbaghia violacea: Its anticoagulant and anti-platelet properties. J Med Plant Res. 2012; 6(33): 4815-4824. [CrossRef]

[8] de la Monte SM, Wands JR. Review of insulin and insulin-like growth factor expression, signaling, and malfunction in the central nervous system: relevance to Alzheimer's disease. J Alzheimer's Dis. 2005; 7 (1): 45-61. [CrossRef]

[9] Neumann KF, Rojo L, Navarrete LP, Farias G, Reyes P, Maccioni RB. Insulin resistance and Alzheimer's disease: molecular links \& clinical implications. Curr Alzheimer Res. 2008; 5(5): 438-447. [CrossRef]

[10] Ünal E, Akan O, Üçler S. Diyabet ve nörolojik hastalıklar. Okmeydanı Tıp Dergisi 2015; 31: 45-51. [CrossRef]

[11] Soylu Ö. Karalı N. Alzheimer Hastalığı ve Tedavisinde Güncel Yaklaşımlar. J Lit Pharm Sci. 2017; 6(2): 94-109. [CrossRef]

[12] Dinççă̆ N. Diabetes mellitus tanı ve tedavisinde güncel durum. İç Hastalıkları Dergisi, 2011; 18(4): $181-223$. [CrossRef]

[13] Chaudhury A, Duvoor C, Dendi R, Sena V, Kraleti S, Chada A, Kuriakose K. Clinical review of antidiabetic drugs: implications for type 2 diabetes mellitus management. Front Endocrinol 2017; 8: 6. [CrossRef]

[14] Inceer H, Hayirlioglu-Ayaz S. Chromosome numbers in Tripleurospermum Sch. Bip. (Asteraceae) and closely related genera: relationships between ploidy level and stomatal length. Plant Syst Evol. 2010; 285(3-4): 149-157. [CrossRef]

[15] Şimşek I, Aytekin F, Yeşilada E, Yıldırımlı Ş. An ethnobotanical survey of the Beypazarı, Ayaş and Güdül district towns of Ankara Province (Turkey). Econ Bot. 2004; 58(4): 705-720. [CrossRef]

[16] Cakilcioglu U, Khatun S, Turkoglu I, Hayta S. Ethnopharmacological survey of medicinal plants in Maden (ElazigTurkey). J Ethnopharmacol. 2011; 137(1): 469-486. [CrossRef]

[17] Nadiroğlu M, Behçet L, Çakılcıoğlu U. An ethnobotanical survey of medicinal plants in Karlıva (Bingöl-Turkey); Ind J Tradit Know. 2019; 18(1): 76-87. [CrossRef]

[18] Altundag E, Ozturk M. Ethnomedicinal studies on the plant resources of east Anatolia, Turkey. Procedia Soc Behav Sci. 2011; 19: 756-777. [CrossRef]

[19] Akaydin G, Şimşek I, Arituluk ZC, Yeşilada E. An ethnobotanical survey in selected towns of the Mediterranean subregion (Turkey). Turk J Biol. 2013; 37 (2): 230-247. [CrossRef]

[20] Javidnia K, Miri R, Soltani M, Khosravi AR. Essential oil composition of Tripleurospermum disciforme from Iran. Chem Nat Compd. 2008; 44(6): 800-801. [CrossRef] 
[21] Chehregani A, Mohsenzadeh F, Mirazi N, Hajisadeghian S, Baghali Z. Chemical composition and antibacterial activity of essential oils of Tripleurospermum disciforme in three developmental stages. Pharm Biol. $2010 ; 48$ (11): 1280-1284. [CrossRef]

[22] Öztürk E, Ozer H, Cakir A, Mete E, Kandemir A, Polat T. Chemical composition of the essential oil of Tripleurospermum corymbosum E. Hossain, an endemic species from Turkey. J Essent Oil-Bear Plants 2010; 13 (2), 148153. [CrossRef]

[23] Kılıç, O, Bağcı E. Chemical composition of essential oil of Tripleurospermum parviflorum (Willd.) pobed (Asteraceae) from Turkey. Asian J Chem. 2012; 24(3): 1319-1321. [CrossRef]

[24] Servi H, Yücel YY, Polatoğlu K. Composition and Acetylcholinesterase inhibition properties of Tripleurospermum inodorum (L.) Sch. Bip. Essential Oil from Istanbul. A J Health Sci 2018; 1(1): 23-38. [CrossRef]

[25] Cavar Zeljkovic S, Ayaz FA, Inceer H, Hayirlioglu-Ayaz S, Colak N. Evaluation of chemical profile and antioxidant activity of Tripleurospermum insularum, a new species from Turkey. Nat Prod Res. 2015; 29(3): 293-296. [CrossRef]

[26] Souri E, Sarkhail P, Kaymanesh P, Amini M, Farsam H. Antioxidant Activity of Extract and a New Isolated Dioxaspiran Derivative of Tripleurospermum disciforme. Pharm Biol. 2005; 43(7): 620-623. [CrossRef]

[27] Tofighi Z, Molazem M, Doostdar B, Taban P, Shahverdi AR, Samadi N, Yassa N. Antimicrobial activities of three medicinal plants and investigation of flavonoids of Tripleurospermum disciforme. Iran J Pharm Res. $2015 ; 14$ (1): 225. [CrossRef]

[28] Özek G, Tekin M, Haliloğlu Y, Başer KHC, Özek T. Chemical compositions of Achillea sivasica: Different plant part volatiles, enantiomers and fatty acids. Rec Nat Prod. 2018; 12 (2): 142. [CrossRef]

[29] Özek G, Özek T, Başer KHC, Duran A, Sagiroglu M, Duman H. Comparison of the essential oils of Prangos turcica A. Duran, M. Sagiroglu et H. Duman fruits obtained by different isolation techniques. J Essent Oil Res, 2006; 18(5): 511-514. [CrossRef]

[30] Göger F, Köse YB, Göger G, Demirci F. Phytochemical characterization of phenolics by LC-MS/MS and biological evaluation of Ajuga orientalis from Turkey. Bangladesh J Pharmacol. 2015; 10 (3): 639-644. [CrossRef]

[31] Göger G, Demirci B, Ilgın S, Demirci F. Antimicrobial and toxicity profiles evaluation of the chamomile (Matricaria recutita L.) essential oil combination with standard antimicrobial agents. Ind Crops Prod. 2018; 120: $279-285$. [CrossRef]

[32] Clinical and Laboratory Standards Institute (CLSI), 2002. Reference method for broth dilution antifungal susceptibility testing of yeast approved standard, M27-A2, Clinical and Laboratory Standards Institute, 940 West Valley Road, Wayne, Pennsylvania, USA.

[33] Clinical and Laboratory Standards Institute (CLSI), 2006. Methods for dilution antimicrobial susceptibility tests for bacteria that grow aerobically CLSI M7-A7, Clinical and Laboratory Standards Institute, 940 West Valley Road, Wayne, Pennsylvania, USA.

[34] Yur S, Tekin M, Göger F, Başer KHC, Özek T, Özek G. Composition and potential of Tanacetum haussknechtii Bornm. Grierson as antioxidant and inhibitor of acetylcholinesterase, tyrosinase, and $\alpha$-amylase enzymes. Int J Food Prop. 2017; 20(3): 2359-2378. [CrossRef]

[35] Ellman GL, Courtney KD, Andres Jr V, Featherstone RM. A new and rapid colorimetric determination of acetylcholinesterase activity. Biochem Pharmacol. 1961; 7(2): 88-95. [CrossRef]

[36] Kürkçüoğlu M, Tosun F, İnceer H, Baser, KHC. Volatile Compounds of Tripleurospermum decipiens from Two Natural Populations in Turkey. Chem Nat Compd. 2019; 55(3): 565-567. [CrossRef]

[37] Ayaz FA, Inceer H, Ayaz-Hayırlığlu S, Kalmuk-Aksu N. Achene fatty acid composition in the tribe Anthemideae (Asteraceae). Rom Biotechnol Lett. 2016; 21 (3): 11576-11584. [CrossRef]

[38] Bakhtiarian A, Ejtemaimehr S, Strobl S, Pournaghash-Tehrani S, Partoazar A, Ghamami G, Yasa N. Inhibition of carrageenan-induced edema by Tripleurospermum disciforme extract in rats. Pak J Biol Sci, 2007; 10(13): $2237-2240$. [CrossRef]

[39] Erdoğan TF, Akkol EK, Süntar I, Gönenç TM, Kıvçak B. Fatty Acid Compositions and Anti-inflammatory Activities of Tripleurospermum parviflorum (Willd.) Pobed. and Tripleurospermum tenuifolium (Kit.). Rec Nat Prod 2015; 9(3): 394. [CrossRef]

[40] Mandegary A, Soodi M, Sharififar F, Ahmadi S. Anticholinesterase, antioxidant, and neuroprotective effects of Tripleurospermum disciforme and Dracocephalum multicaule. J Ayurveda Integr Med. 2014; 5(3): 162. [CrossRef] 
[41] Minaiyan M, Ghassemi-Dehkordi N, Mohammadzadeh B, Anti-ulcer effect of Tripleurospermum disciforme (CA Mey) Shultz Bip on pylorus ligated (Shay) rats. Res Pharm Sci. 2007; 1(1): 15-21. [CrossRef]

[42] Parvini S, Hosseini MJ, Bakhtiarian A. The study of analgesic effects and acute toxicity of Tripleurospermum disciforme in rats by formalin test. Toxicol Mech Methods, 2007; 17(9): 575-580. [CrossRef]

[43] Rethy B, Csupor-Löffler B, Zupko I, Hajdu Z, Mathe I, Hohmann J, Redei T, Falkay G. Antiproliferative activity of Hungarian Asteraceae species against human cancer cell lines. Part I. Phytother Res. 2007; 21(12): 1200-1208. [CrossRef]

[44] Tosun F, Akyüz Kızılay Ç, Şener B, Vural M. The evaluation of plants from Turkey for in vitro antimycobacterial activity. Pharm Biol. 2005; 43(1): 58-63. [CrossRef]

[45] Erdoğan TF, Gönenç TM, Oskay M. Antimicrobial and cytotoxic activities of Tripleurospermum parviflorum (Willd.) Pobed. Marmara Pharm J. 2013; 1 (1): 12-14. [CrossRef]

[46] Sarper F, Akaydin G, Şimşek I, Yeşilada E. An ethnobotanical field survey in the Haymana district of Ankara province in Turkey. Turk J Biol. 2009; 33(1): 79-88. [CrossRef]

[47] Özüdoğru B, Akaydın G, Erik S, Yesilada E. Inferences from an ethnobotanical field expedition in the selected locations of Sivas and Yozgat provinces (Turkey). J Ethnopharmacol. 2011; 137(1): 85-98. [CrossRef]

[48] Özgen U, Kaya Y, Houghton P. Folk medicines in the villages of Ilıca District (Erzurum, Turkey). Turk J Biol. 2012; 36 (1): 93-106. [CrossRef]

[49] Han Mi, Bulut G. The folk-medicinal plants of Kadisehri (Yozgat-Turkey). Acta Soc Bot Pol 2015; 84(2): $237-248$. [CrossRef]

[50] Günbatan T, Gürbüz İ, Özkan AMG. The current status of ethnopharmacobotanical knowledge in Çamlıdere (Ankara, Turkey). Turk J Botany. 2016; 40 (3): 241-249. [CrossRef]

[51] Yaşar A, Üçüncü O, Güleç C, İnceer H, Ayaz S, Yaylı N. GC-MS Analysis of Chloroform Extracts in Flowers, Stems, and Roots of Tripleurospermum callosum. Pharm Biol, 2005; 43 (2): 108-112. [CrossRef]

[52] Iversen CK, Jakobsen HB, Olsen CE. Aroma changes during black currant (Ribes nigrum L.) nectar processing, J Agric Food Chem. 1998; 46(3): 1132-1136. [CrossRef]

[53] Krupcik J, Matisova E, Garaj J, Sojak L, Brezkin VG. Contribution of adsorption to retention data in glass capillary gas chromatography. Part. I. Polar stationary phases, Chromatographia. 1982; 16(1): 166-168. [CrossRef]

[54] Yasuda T, Higuchi H. Sex pheromones of Stenotus rubrovittatus and Trigonotylus caelestialium, two mirid bugs causing pecky rice and their application to insect monitoring in Japan. Psyshe. 2012; 1-8. [CrossRef] 